\title{
Drought-induced tree death in savanna
}

\author{
$<$ R.J. Fensham ${ }^{1}$, R.J. Fairfax ${ }^{1}$ \& D.P. Ward ${ }^{2}$ \\ ${ }^{1}$ Queensland Herbarium, Environmental Protection Agency, Mt Coot-tha Road, \\ Toowong, Queensland 4068, Australia; ${ }^{2}$ The Ecology Centre, University Of \\ Queensland, St Lucia, Queensland, 4072
}

Woody plant encroachment is well-documented in savannas and could represent a significant anthropogenic carbon sink through the response of woody plants to increased atmospheric $\mathrm{CO}_{2}{ }^{1,2}$ and manipulation by rangeland management ${ }^{3-6}$. However, xeric areas of the savanna biome have unreliable rainfall and are subject to substantial multi-year rainfall deficit. Data from four continents suggests extreme drought events coincide with extensive tree death ${ }^{7-15}$. An analysis of randomly located individual sites in an Australian savanna region indicates that woody cover change is influenced by relative rainfall. This relationship is moderated by density dependence, whereby growth is facilitated with low woody cover and drought-induced dieback is more likely in places with relatively high woody cover. The importance of rainfall patterns is also verified at the regional scale because increases in woody cover during a period of above-average rainfall were offset by an equivalent decrease through drought. Rainfall excess and deficit is a powerful determinant of woody vegetation dynamics in xeric savanna ${ }^{16}$, and in an Australian savanna can override effects of contemporary and historical land management or $\mathrm{CO}_{2}$ fertilization. However, tree-death episodes will become a stark consequence of global change if predictions of increasing severity and frequency of drought ${ }^{17}$ are realised.

Increasing woody plant biomass in savannas is predicted where frequent burning by indigenous people has been replaced by rangeland pastoralism ${ }^{18}$. Livestock consume grass, fires become less frequent or intense and tree survival and accession into the upper canopy is enhanced. Woody plant increase may also be promoted by atmospheric $\mathrm{CO}_{2}$ fertilization, which is predicted to favour woody plants through preferential advantage for the C3 over C4 photosynthetic pathway ${ }^{19}$. Increased water-use efficiency results in subsequent deeper percolation of water ${ }^{1}$ which further advantages deeper rooted plants. Greater growth rates also result and increase the likelihood of stem survival between fires ${ }^{2,20}$. Even small increases in woody biomass, if they occur throughout the world's $16.1 \mathrm{M} \mathrm{km}^{2}$ of grazed savanna ${ }^{21}$ represent a substantial carbon $\sin ^{5,22}$. Woody encroachment and tree death have positive and negative consequences depending on land-use, and both have been viewed as symptoms or forms of land degradation.

Models of savanna function tend to incorporate water-use in relation to average climate variables and land-use as dominant influences on woody plants ${ }^{18,23,24}$. Some empirical studies of woody vegetation change highlight the powerful influence of multiyear rainfall excess and deficit ${ }^{25}$. This paper improves our understanding of the role of rainfall variability by employing a global analysis of drought, and tree cover change from a case-study to answer two questions: 
1) Is tree death related to patterns of multi-year drought in savanna environments?

2) Is there an underlying trend of increasing woody cover that is independent of rainfall patterns?

Global patterns of savanna rainfall were examined using a simple index describing the most substantial 3-yr rainfall deficit over the last 102 years. The more xeric the savanna environments, the more extreme are the droughts (Fig. 1). This relationship varies between the continents, such that a minimum value of the 3-yr rainfall index of -1.0 (two-thirds of expected rainfall) on average coincides with $520 \mathrm{~mm}$ mean annual rainfall in Europe and $1302 \mathrm{~mm}$ in Australasian savanna (Fig. 1). Records of droughtinduced tree death in savanna environments were collated and displayed in the context of annual rainfall and drought severity (Fig. 1). The droughts coinciding with tree death studies were least intense for Kruger (3-year rainfall index of -0.76) and most intense for Senegal II (3-year rainfall index of -1.82). With the exception of the Senegal I and Kruger studies, the droughts documented by the studies collated here are the most intense for the 102 year record (Fig. 1). In north-eastern Australia, records of previous more extreme droughts commencing prior to 1901 (Fig. 2) also caused substantial tree death $^{15}$.

A 40,000 $\mathrm{km}^{2}$ case-study region from savanna in north-east Australia (Study region 7; Fig. 1) was chosen to search for a trend of increasing woody cover that is independent of rainfall. The area is well-suited to this investigation because it is represented by aerial photography spanning both wet and dry periods, has been subject to uniform rangeland pastoralism spanning the study period, and manual removal of woody vegetation is uncommon. The technique employed to assess woody vegetation cover from the aerial photography produced assessments that were significantly correlated with various field measurements taken from the study sites in 1997 (see Supplementary Information).

The 3-yr rainfall index demonstrated three major drought episodes over the twentieth century: from 1900-1908, a second less intense drought from 1929-1936, and the drought from 1993-1998 coinciding with the $t_{2}-t_{3}$ period (Fig. 2). The intensity of these droughts varied slightly across the region, but generally the 1900-1904 drought was the most severe. The 3-yr rainfall index was mostly negative between 1928 and 1942 preceding the aerial photography record. $\mathrm{T}_{1}-\mathrm{T}_{2}$ encompasses two extremely wet periods between 1954-1961 and 1972-1978 (Fig. 2).

Modelling across the individual site-period combinations demonstrated a positive relationship between Woody cover change rate and Relative rainfall (Fig. 3). The model also includes a density dependence effect whereby sites with a relatively open structure are more likely to increase woody cover and sites with high woody cover more likely decline (Fig. 3). The function describing these relationships has a negative intercept suggesting there is not a substantial trend for positive cover increase underlying that driven by rainfall. The implication of the density dependence effect is that the relatively open structure created by the severe droughts in the first half of the twentieth century (Fig. 2) would exaggerate woody cover increase than otherwise predicted by rainfall 
alone. The model predicts gradual increase in cover during average or wet times and a decline in cover coincident with severe drought.

This prediction is supported by interpreting the average changes in woody cover in the context of the regional rainfall history (Fig. 2). The average value for Relative rainfall for the $t_{1}-t_{2}$ period (1946-1990) is positive (1.046; range 1.009-1.122). This period corresponds with an increase in average woody cover from $21.7 \%$ to $26.0 \%$, with an annual absolute change rate of $0.104 \%$ per year. For the $T_{2}-T_{3}$ period (1990-2002) Relative rainfall is below average (0.870; range 0.726-1.042). Woody cover decreased to $21.4 \%$, declining at $-0.412 \%$ per year. The overall average Relative rainfall $\left(\mathrm{t}_{1}-\mathrm{t}_{3}\right)$ was very slightly positive (1.010), and the overall change in rate of woody cover was effectively zero $\left(-0.004 \% \cdot y^{1}\right)$. There is no underlying trend of increase during the almost neutral rainfall conditions spanning the entire period, and woody vegetation change at the regional scale can be interpreted in the context of rainfall history and density dependence. Severe droughts early in the twentieth century decimated tree stocks, which recovered gradually. The increases in cover have been facilitated by low competition, but would have accelerated during the wet 1950s and 1970s (Fig. 2). As tree stocks recovered, competition intensifies, such that the woody component of the savannas becomes increasingly vulnerable to low soil moisture. Extensive tree death during the extreme drought of the 1990s was an inevitable consequence and has re-set the savanna to a more open state to complete this dynamic cycle (Fig. 2).

The critical importance of inter-annual rainfall variation influencing tree stocks is supported by a recent dynamic vegetation model ${ }^{16}$, but the accuracy of future attempts to model woody vegetation dynamics in savanna will require further development of the soil-water balance component in relation to drought. This is highlighted by the wide variation in the spatial extent of tree death during the late 1990s drought in north-east Australia (Fig. 3). Soil moisture is moderated at local scales by patchiness of rainfall, the standing stock of woody vegetation and soil properties ${ }^{16,26}$ and is extremely difficult to model accurately ${ }^{27}$.

We propose that there is a profound difference in the ecology of xeric and mesic savanna environments. The cut-off between these types may in general terms be defined by mean annual rainfall, but will vary between continents and regions (Fig. 1), and will depend on the susceptibility of the tree species ${ }^{7,15}$. In the more xeric savannas rainfall deficit over multiple years results in the exhaustion of moisture reserves ${ }^{26,28}$, resulting in tree death caused by xylem cavitation ${ }^{29}$. Drought-induced tree death seems to be an infrequent, but natural disturbance phenomenon that inevitably counteracts woody plant increase during the long periods when deep soil moisture can sustain woody plant growth. In savanna environments with higher rainfall the wet season is probably sufficiently reliable that drought-induced tree death is not such a critical ecological process. In these environments woody plant increase in responses to management, such as changed fire regime, and increased woodiness due to enhanced atmospheric $\mathrm{CO}_{2}$ may be more sustained.

The combined effects of land-use and $\mathrm{CO}_{2}$ fertilization do not seem be generating a sustained positive growth response in the woody plants of drought-prone Australian savanna. This study has also demonstrated that tree death is a dramatic consequence of 
drought across a number of continents. However, more research is required to determine the magnitude and cause of fluxes in woody plants throughout the savanna biome. The implication from our Australian case study is that enhanced levels of atmospheric $\mathrm{CO}_{2}$, or land-uses with low fire frequency or intensity will not yield a sustained carbon sink in xeric savanna environments.

A doubling in the frequency of severe droughts has been predicted under future climate scenarios ${ }^{17}$. The physiological effect of drought on trees may well be enhanced by rising temperatures, which have recently been interpreted as exacerbating tree death in the southern USA ${ }^{8}$. Enhanced drought conditions will intensify tree-death which is likely to be a symptom of global climate change.

\section{Methods Summary}

For each $0.5^{0} \times 0.5^{0}$ cell within the savanna biome (see Supplementary Methods for details and additional analyses) a 3-yr rainfall index was calculated from monthly rainfall data from 1901-2002 (http://www.cru.uea.ac.uk/ timm/grid/CRU TS 2 1.html). The index is calculated as actual annual rainfall for three years prior to every month less expected rainfall for that period, divided by the mean annual rainfall. Minimum values for each cell are presented in Fig. 1. Studies of drought-related tree death were included in the global collation if density, woody cover or basal area change of dominant trees were quantified and attributed as a drought related decline from within the savanna biome (Fig. 1).

The 101 sites from the north-east Australia study corresponded with randomly located field survey sites ${ }^{15}$. Percentage aerial cover of woody vegetation was determined from aerial photography at three times (Fig. 2) using calibrated models ${ }^{30}$.

Woody cover change rate $\left(\% \mathrm{y}^{-1}\right)$ was determined as the change in percentage aerial cover over a site-period, divided by the duration of that site-period. Forward stepwise linear models related Woody cover change rate to predictive variables including:

1) Relative initial cover calculated as the cover at the start of a period divided by the $10^{\text {th }}$ percentile for all cover measurements $\left(t_{1}, t_{2}\right.$ and $\left.t_{3}\right)$ within each land type.

2) Relative rainfall for each site-period, represented as the actual rainfall for a period divided by the expected rainfall based on the long-term record. Monthly rainfall records were interpolated from actual rainfall data (http://www.nrm.qld.gov.au/silo). Interpolated rainfall records are informed by 32 stations in the 1890s, 69 in the 1940s, 118 in the 1970s, and 92 in the 2000s.

1 Polley, H.W., Mayeux, H.S., Johnson, H.B. \& Tischler, C.R. Viewpoint: atmospheric $\mathrm{CO} 2$, soil water, and shrub/grass ratios on rangelands. J. Range. Manage. 50, 278-284 (1997).

2 Hoffmann, W.A., Bazzaz, F.A., Chatterton, N.J., Harrison, P.A. \& Jackson, R.B. Elevated CO2 enhances resprouting of a tropical savanna tree. Oecologia 123, 312-317 (2000). 
Archer, S. Tree-grass dynamics in a Prosopis-thornscrub savanna parkland: Reconstructing the past and predicting the future. Ecoscience 2, 83-99 (1995). Asner, G.P., Archer, S., Flint Hughes, R., James Ansley, R. \& Wessman, C.A. Net changes in regional woody vegetation cover and carbon storage in Texas drylands, 1937-1999. Global Change Biol. 9, 316-335 (2003). Burrows, W.H. et al. Growth and carbon stock change in eucalypt woodlands in northeast Australia: ecological and greenhouse sink implications. Global Change Biol. 8, 769-784 (2002).

Silva, J.F., Zambrano, A. \& Farinas, M.R. Increase in the woody component of seasonal savannas under different fire regimes in Calabozo, Venezuela. $J$. Biogeogr. 28, 977-983 (2001). Mueller, R.C. et al. Differential tree mortality in response to severe drought: evidence for long-term vegetation shifts. J. Ecol. 93, 1085-1093 (2005). Breshears, D.D. et al. Regional vegetation die-off in response to global-changetype drought. Proc. Natl. Acad. Sci. USA 102, 15144-15148 (2005). Archer, S., Scifres, C., Bassham, C.R. \& Maggio, R. Autogenic succession in subtropical savanna: conversion of grassland to thorn woodland. Ecol. Monogr. 58, 111-127 (1988). Poupon, H. \& Bille, J.C. Recherches ecologiques sur une savane sahelienne du Ferlo septentrional, Senegal: Influence de la secheresse de l'annee 1972-1973 sur la strate ligneuse. La Terre et la Vie 28, 49-75 (1974). Gonzalez, P. Desertification and shift of forest species in the West African Sahel. Clim. Res. 17, 217-228 (2001). climate-induced changes in woody vegetation in the Sudan, 1943-1994. Global Change Biol. 2, 137-141 (1996).

Viljoen, A. J. The influence of the 1991/92 drought on the woody vegetation on the Kruger National Park. Koedoe 38, 85-97 (1995).

Khan, J.A., Rodgers, W.A., Johnsingh, A.J.T. \& Mathur, P.K. Tree and shrub mortality and debarking by sambar Cervus unicolor (Kerr) in Gir after a drought in Gujarat, India. Biol. Conserv. 68, 149-154 (1994).

Fensham, R.J. \& Holman, J.E. Temporal and spatial patterns in drought-related tree dieback in Australian savanna. J. Appl. Ecol. 36, 1035-1050 (1999). Fernandez-Illescas, C.P. \& Rodriguez-Iturbe, I. Hydrologically driven hierarchical competition-colonization models: the impact of interannual climate fluctuations. Ecol. Monogr. 73, 207-222 (2003).

Burke, E.J., Brown, S.J. \& Christidis, N. Modeling the recent evolution of global drought and projections for the twenty-first century with the Hadley Centre Climate Model. J. Hydrometeorol. 7, 1113-1125 (2006).

Scholes, R.J. \& Archer, S.R. Tree-grass interactions in savannas. Annu. Rev. Ecol. Syst. 28, 517-544 (1997).

Ainsworth, E.A. \& Long, S.P. What have we learned from 15 years of free-air $\mathrm{CO} 2$ enrichment (FACE)? A meta-analytic review of the responses of photosynthesis, canopy properties and plant production to rising CO2. New Phytol. 165, 351-372 (2005).

Bond, W.J. \& Midgley, G.F. A proposed $\mathrm{CO}_{2}$ controlled mechanism of woody plant invasion in grasslands and savannas. Global Change Biol. 6, 865-869 (2000). 
Scholes, R. \& Hall, D.O. Global change: effects in coniferous forests and grasslands (eds A.I. Breymeyer, D.O. Hall, J.M. Melilo et al.) 69-100 (John Wiley \& Sons, Chichester, 1996). Houghton, R.A., Hackler, J.L. \& Lawrence, K.T. The U.S. carbon budget: contributions from land-use change. Science 285, 574-578 (1999). Jeltsch, F., Weber, G.E. \& Grimm, V. Ecological buffering mechanisms in savannas: A unifying theory of long-term tree-grass coexistence. Plant Ecol. 161, 161-171 (2000). Sankaran, M. et al. Determinants of woody cover in African savannas. Nature 438, 846-849 (2005). Fensham, R.J., Fairfax, R.J. \& Archer, S. Rainfall, land-use and woody vegetation cover change in semi-arid Australian savanna. J. Ecol. 93, 596-606 (2005). Fensham, R.J. \& Fairfax, R.J. Drought-related tree death of savanna eucalypts: species susceptibility, soil conditions and root architecture. J. Veg. Sci. 18, 71-80 (2007). Western, A.W., Grayson, R.B. \& Blöschl, G. Scaling of soil moisture: A hydrologic perspective. Annu. Rev. Earth Pl. Sc. 30, 149-180 (2002). Bowman, D.M.J.S. \& Prior, L.D. Why do evergreen trees dominate the Australian seasonal tropics? Aust. J. Bot. 53, 379-399 (2005). Rice, K.J., Matzner, S.L., Byer, W. \& Brown, J.R. Patterns of tree dieback in Queensland, Australia: the importance of drought stress and the role of resistance to cavitation. Oecologia 139, 190-198 (2004). Fensham, R.J. \& Fairfax, R.J. Effect of photo scale, interpreter bias and land type on woody crown cover estimates from aerial photography. Aust. J. Bot. 55, 457-463 (2007). 
'Supplementary Information accompanies the paper on www.nature.com/nature.’

The Tropical Savannas CRC and Land \& Water Australia are thanked for financial support for these studies. Gordon Guymer, Alex Kutt, Don Butler and Bob Sutherst provided useful comments on the manuscript. Alan Beswick is thanked for supply of the SILO data and Jack Kelley for writing the program that interrogated that data. Craig Allen, Neil Cobb, Lisa Floyd-Hanna, Richard Trotter provided unpublished methodological details.

Correspondence and requests for materials should be addressed to R. Fensham (rod.fensham@epa.qld.gov.au).

Figure 1. The world's savanna environments (Tropical moist deciduous forest, Tropical dry forest, Tropical Shrubland, Subtropical dry forest and Subtropical steppe from Food and Agricultural Organization Ecological zones, http://www.fao.org/documents/show_cdr.asp?url_file=/docrep/006/ad652e/ad652e 07.htm) coloured according to the minimum value of the 3-yr rainfall index over 102 years. Studies of drought-induced tree death and are located, 1 Arizona $\mathbf{~}^{7}$; 2 Arizona $I^{8}, 3$ Colorado $^{8}, 4$ Texas $^{9} ; 5$, Senegal II, 6 Senegal III; 4 Sudan ${ }^{12} ; 5$ Kruger $^{13} ; 6$ Gujarat ${ }^{14} ; 7$ North-east Australia ${ }^{15}$. The relationship between mean annual rainfall and the minimum 3-yr Rainfall Index is expressed for each continent. The intensity of the drought described in the above studies is indicated by the diamond symbols. Tree death estimates (see Supplementary notes): Arizona, 29\%; Texas, 38\%; Senegal I 33\%; Senegal II 22\%; Sudan 14\%, Kruger 13\%, Gujarat 17\%; North-east Australia 29\%.

Figure 2. Average 3-yr rainfall Index for the 101 sites across the north-east Australia study area (solid line with standard error), and the average woody cover (and standard error) between $\mathrm{t}_{1}, \mathrm{t}_{2}$ and $\mathrm{t}_{3}$.

Figure 3. Change rate vs relative initial cover for all site-periods. Change from $t_{1}-t_{2}$ is represented by circles and $t_{2}-t_{3}$ by squares. Dashed lines indicate neutral rainfall conditions and neutral Woody cover change. The text in each quadrant is the average relative initial cover, standard error and $\mathrm{n}$ for sites within that quadrant. The form of the model is: Woody cover change rate $=0.437-$ $2.547(\log [$ Relative initial cover +1$])+2.131$ (Relative rainfall $\times($ log[Relative initial cover+1])). The $\mathrm{R}^{2}$ of the model is $33.82 \%$.

Figure 4. Australian eucalypt savanna woodland with extensive tree death resulting from a drought in the late 1990s. Mean annual rainfall at this site is about $500 \mathrm{~mm}$. 


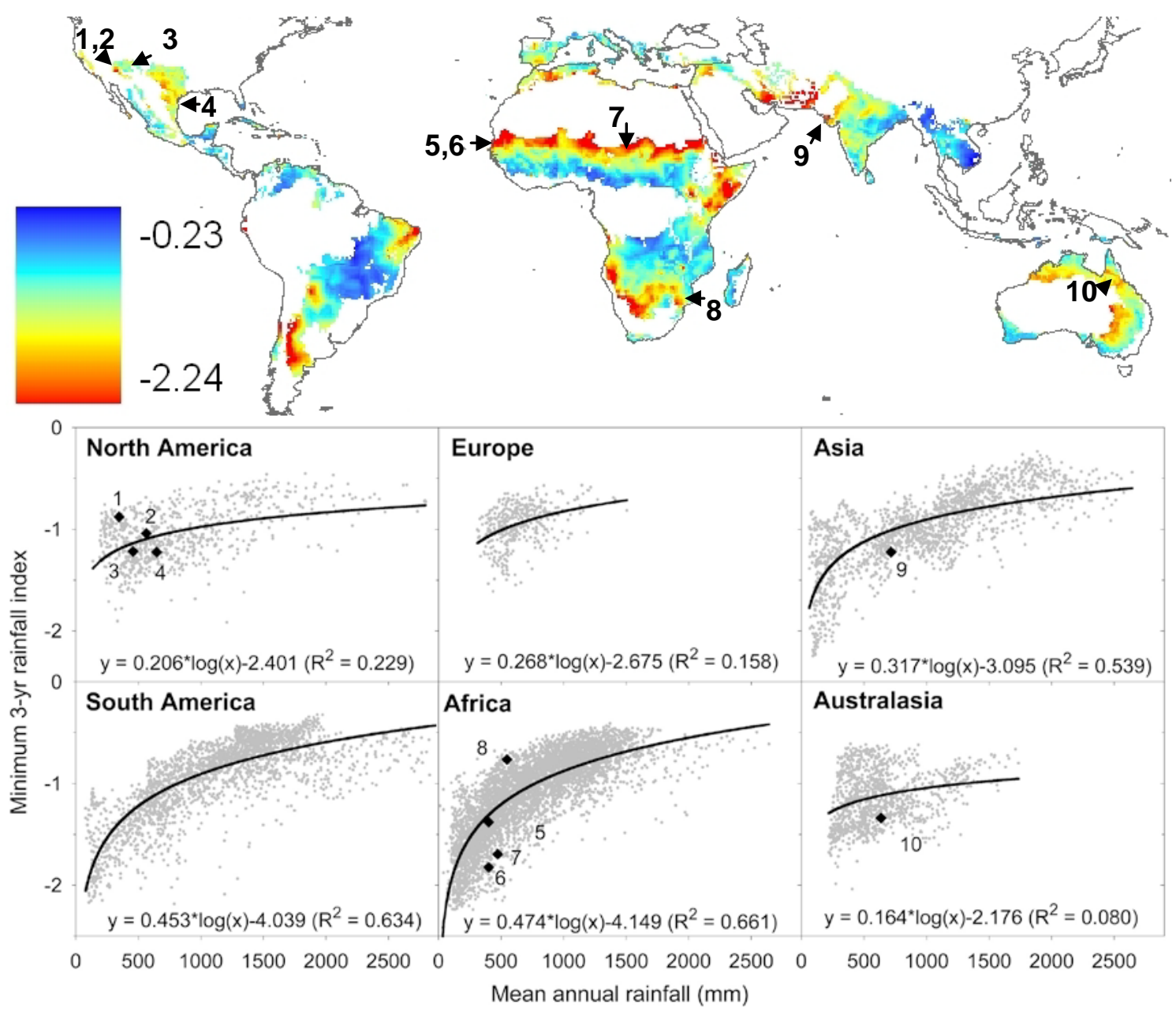

Figure 1 


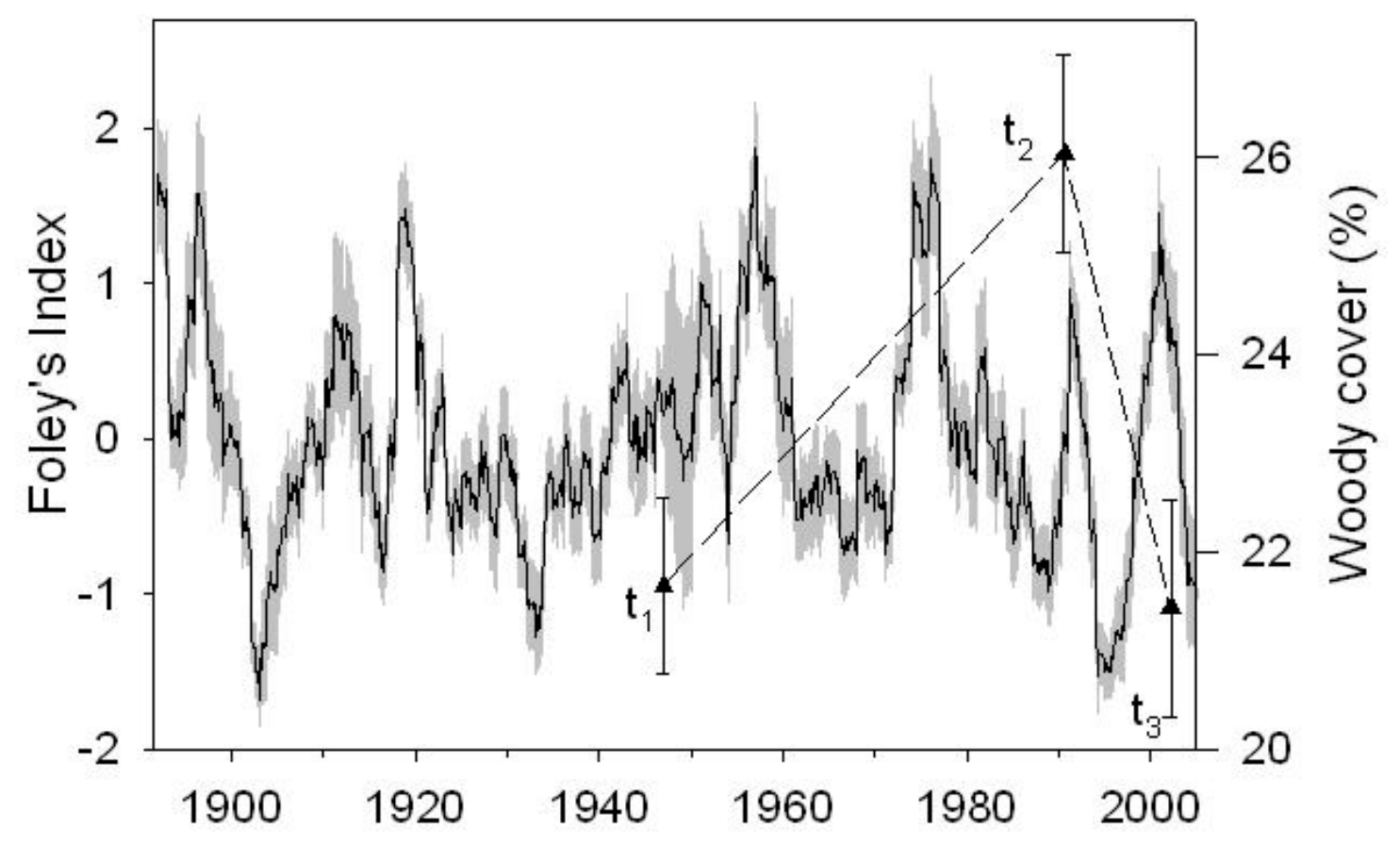

Figure 2 


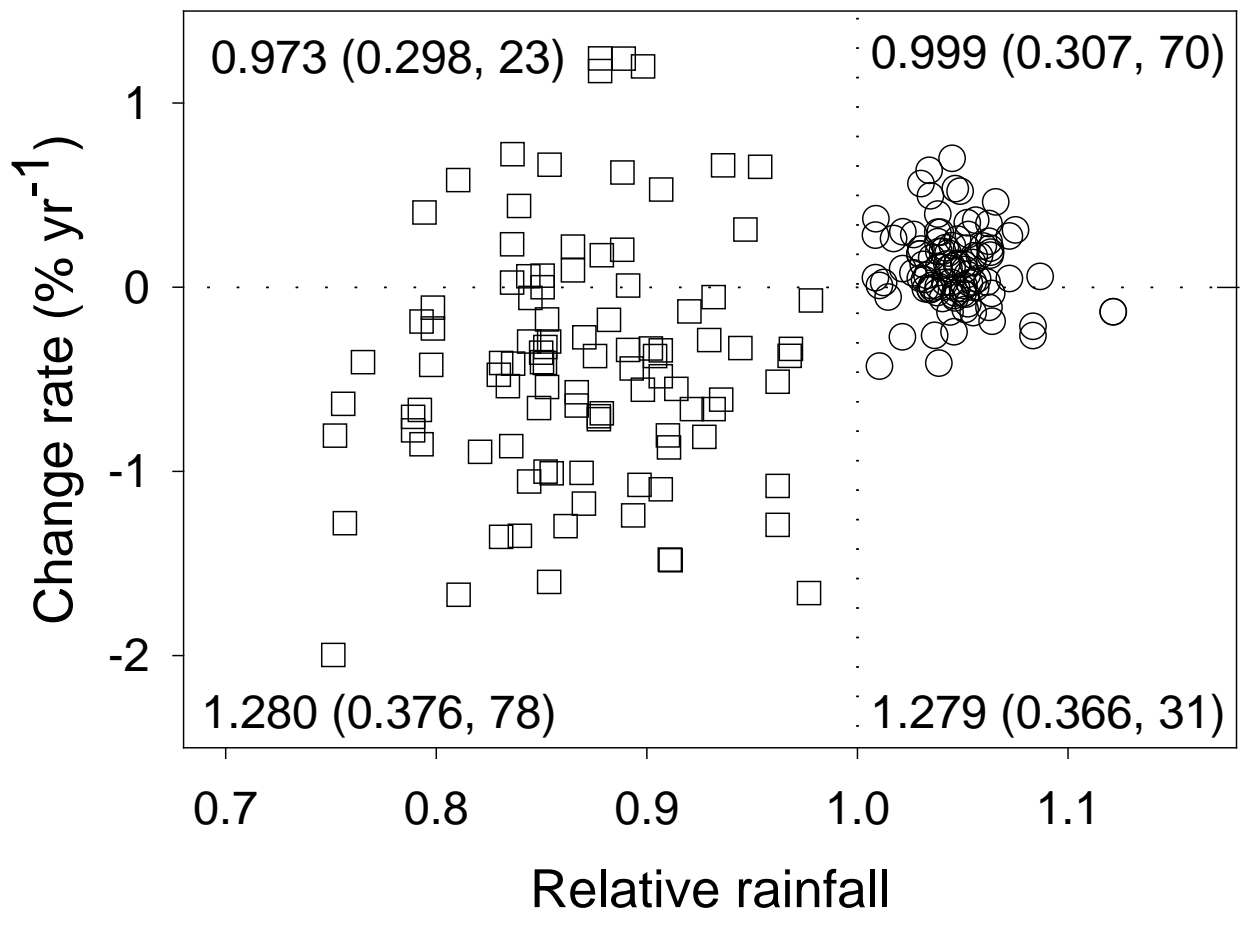

Figure 3 


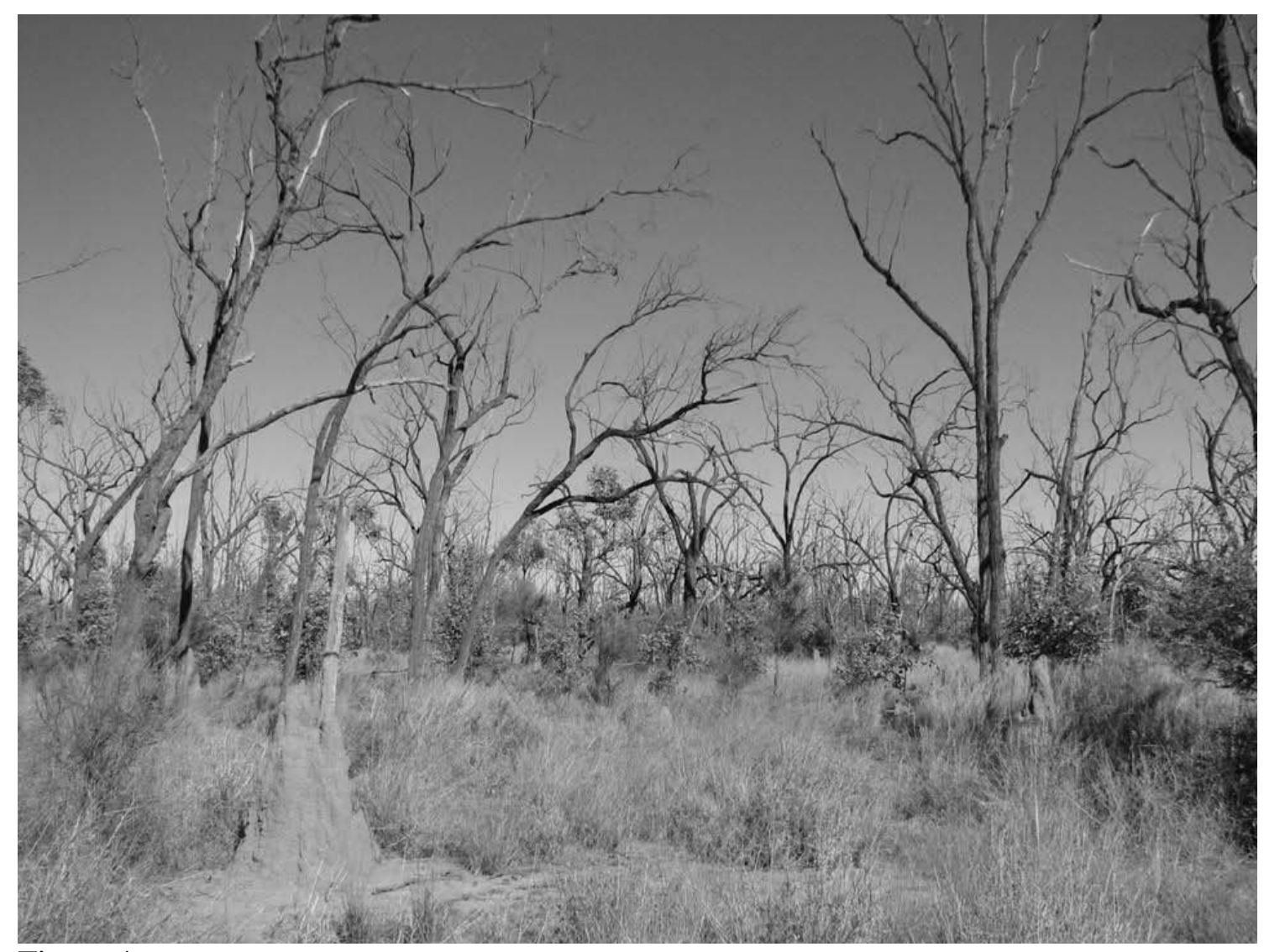

Figure 4 